\title{
Correction to: Temporal trend of research related to gun violence from 1981 to 2018 in the United States: a bibliometric analysis
}

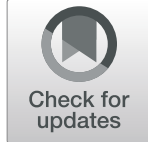

\author{
Lung-Chang Chien ${ }^{1 *}$, Maxim Gakh ${ }^{1}$, Courtney Coughenour ${ }^{1}$ and Ro-Ting Lin ${ }^{2}$
}

Correction to: Inj Epidemiol (2020) 7:9

https://doi.org/10.1186/s40621-020-0235-6

Following publication of the original article (Chien et al. 2020), the authors identified two errors;

1) The equations were not adequately presented since they all Greek symbols disappeared in the PDF version of the article.

The correct presentation of the equations is given below.

$\log \left(\mathrm{NP}_{\mathrm{t}}\right)=\alpha+\beta \times \mathrm{t}+\log \left(\right.$ Total $\left._{\mathrm{t}}\right)$, where $\mathrm{t}=1, \ldots, 38$

\section{Author details}

${ }^{1}$ Department of Environmental and Occupational Health, School of Public Health, University of Nevada, Las Vegas, 4700 S. Maryland Pkwy, Suite 335, Las Vegas, Nevada 89119, USA. ${ }^{2}$ Department of Occupational Safety and Health, College of Public Health, China Medical University, No. 91, Xueshi Road, North District, Taichung City 404, Taiwan.

Published online: 13 July 2020

\section{Reference}

Chien L, Gakh M, Coughenour C, et al. Temporal trend of research related to gun violence from 1981 to 2018 in the United States: a bibliometric analysis. Inj Epidemiol. 2020;7:9 https://doi.org/10.1186/s40621-020-0235-6.

$$
\begin{aligned}
\log \left(\mathrm{NP}_{\mathrm{it}}\right)= & \alpha+\alpha_{\mathrm{i}(\mathrm{t})}+\beta_{1} \times \mathrm{l}(\mathrm{i}=1)+\beta_{2} \times \mathrm{I}(\mathrm{i}=2) \\
& +\mathrm{f}(\mathrm{t})+\log \left(\text { Total }_{\mathrm{it}}\right),
\end{aligned}
$$

where $\mathrm{i}=1,2,3 ; \mathrm{t}=1, \ldots, 38$

2) The grey horizontal lines were missing in Fig. 1.

The correct figure is given below.

The original article (Chien et al. 2020) has been updated.

* Correspondence: lung-chang.chien@unlv.edu

'Department of Environmental and Occupational Health, School of Public

Health, University of Nevada, Las Vegas, 4700 S. Maryland Pkwy, Suite 335, Las Vegas, Nevada 89119, USA

Full list of author information is available at the end of the article

C C The Author(s). 2020 Open Access This article is licensed under a Creative Commons Attribution 4.0 International License, which permits use, sharing, adaptation, distribution and reproduction in any medium or format, as long as you give appropriate credit to the original author(s) and the source, provide a link to the Creative Commons licence, and indicate if changes were made. The images or other third party material in this article are included in the article's Creative Commons licence, unless indicated otherwise in a credit line to the material. If material is not included in the article's Creative Commons licence and your intended use is not permitted by statutory regulation or exceeds the permitted use, you will need to obtain permission directly from the copyright holder. To view a copy of this licence, visit http://creativecommons.org/licenses/by/4.0/ The Creative Commons Public Domain Dedication waiver (http://creativecommons.org/publicdomain/zero/1.0/) applies to the data made available in this article, unless otherwise stated in a credit line to the data. 


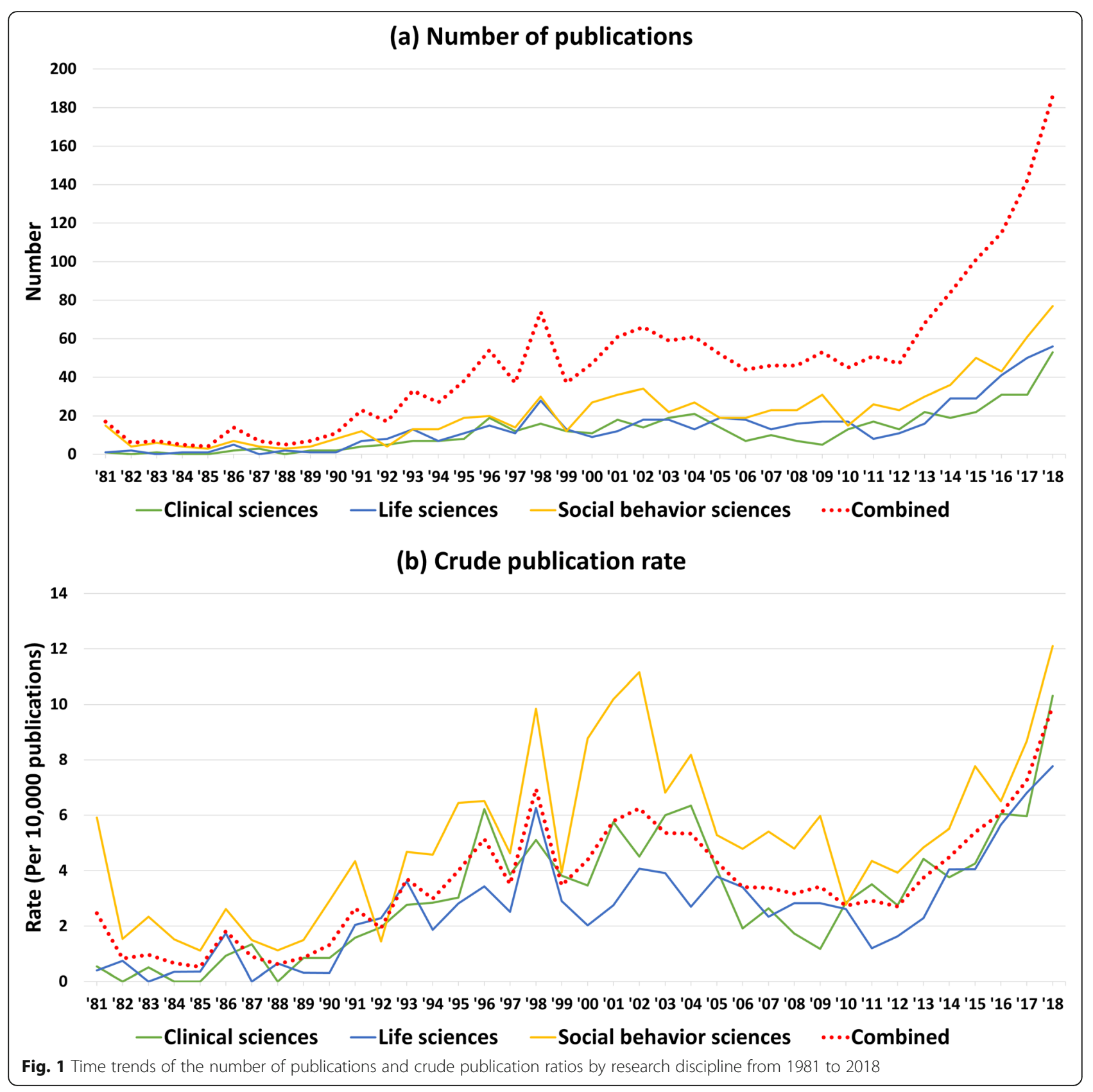

